\title{
Performing the Return of the Repressed: Krzysztof Wodiczko's Artistic Interventions in New York City's Public Space
}

Justyna Wierzchowska

\section{(2) OpenEdition}

\section{Journals}

Electronic version

URL: https://journals.openedition.org/ejas/11308

DOI: $10.4000 /$ ejas. 11308

ISSN: 1991-9336

Publisher

European Association for American Studies

Electronic reference

Justyna Wierzchowska, "Performing the Return of the Repressed: Krzysztof Wodiczko's Artistic Interventions in New York City's Public Space", European journal of American studies [Online], 10-3 2015, document 1.6, Online since 31 December 2015, connection on 08 July 2021. URL: http:// journals.openedition.org/ejas/11308; DOI: https://doi.org/10.4000/ejas.11308

This text was automatically generated on 8 July 2021 .

Creative Commons License 


\title{
Performing the Return of the Repressed: Krzysztof Wodiczko's Artistic Interventions in New York City's Public Space
}

\author{
Justyna Wierzchowska
}

In this paper, I want to discuss two projections ${ }^{1}$ by Polish-born and New York-based artist Krzysztof Wodiczko that make use of public space and treat it a vehicle of artistic and political interventionism. Addressing major ailments of modern societyhomelessness and the psychological effects of war-the two projections share the location of Union Square in New York, and the mode of execution: casting images on neoclassical statues featuring American national heroes and the Allegory of Charity. While the first projection, The Homeless Projection: A Proposal for Union Square[for the city of New York] (1986), ${ }^{2}$ has never in fact been executed on location, ${ }^{3}$ the other one, Abraham Lincoln: War Veteran Projection, was on view every evening for a month between October 8 and November 9, 2012. During that time "the immobile statue [of Abraham Lincoln] was animated with gestures and voices that made it part of the public debate on war and the fate of veterans." ${ }^{4}$ The 1986 projection was conceived in the context of a massive yet controversial revitalization of the city of New York carried out throughout the 1980s, the latter brought a heart-jerking comment on the psychological effects of the war in Afghanistan and Iraq. In the case of both, the statues of American heroes functioned as ideologically-charged screens upon which expressions of the usually marginalized ailments were cast. The projections offered a critique of what after Frederick Engels Rosalyn Deutsche has identified as "beautified surfaces, suppressed contradictions, and relocated problems." ${ }^{5} \mathrm{My}$ goal in this paper is to present the subversive potential of the two works, but at the same time discuss their inherent problematics. It is my belief that while such artistic interventions are philosophically charged and intellectually sophisticated, they necessarily fail to effectively deliver the rich theoretical framework to a wider audience. At the same time, by enabling spectators to go through an "embodied experience," the projections may affect them in 
an immediate way. This "embodied experience" may translate into a crack in the spectators' perception of what is commonly taken for granted, and, eventually, into their individual questioning of the dominant ideology.

Since the 1970s, Krzysztof Wodiczko has engaged in artistic/political interventions in the public space and has carried out almost a hundred projections in various cities around the world. ${ }^{6} \mathrm{He}$ works in the urban space and he believes that the "city is the stage and stake of democracy." His choice of ideologically-charged structures, located in the public space, very often in busy city-centers (as is the case of Union Square), involves an element of surprise, as one may actually happen to witness a projection and there is no entry fee. In his projections, Wodiczko temporarily appropriates the most spectacular sites of hegemonic authority such as civic buildings, monuments and memorials by projecting upon them images and/or testimonies of the excluded (e.g. war veterans, immigrants, the homeless, the victimized etc.). ${ }^{8} \mathrm{~A}$ very good example of Wodiczko's work is a 1986 projection carried out in Pittsburgh, PA, on the façade of the Allegheny County Memorial Hall. The Allegheny Hall is the largest memorial to honor all branches of military veterans in the USA, commemorating over 600 recipients of military awards, medals, stars and crosses in the "Hall of Valor." On its façade, Wodiczko displayed an image of a huge accordion played by the bony hands of a skeleton. The image perfectly filled in the silhouette of the building, with the neoclassical columns smoothly incorporated as a core part of the image. Thus Wodiczko projected a sign that might be associated with the dance macabre over a building that celebrates the military in its most alluring dimension: unambivalently heroic and honorable. More than that, he did so on an architectural structure that, by its noble, classical, and authoritarian look, effectively aestheticizes and thus conceals the incoherence and contradictions of its contents. This way the building itself, mostly because of its ethically-questionable grandeur and fake ideological neutrality, became part of the dance macabre.

The Allegheny Hall example demonstrates how civic architecture, which acts like a stabilizing agent of the official version of history and the present-day recognition of political authority, ${ }^{9}$ is taken by Wodiczko as a starting point for his artistic interventionism. When during a projection another, conflicting image/narrative is cast on its surface, the very often unconsciously internalized acknowledgement of the hegemonic discourse is suddenly brought to attention. Because the image/narrative projected on the surface undermines the coherence of the one underneath, the original meaning is evoked with its inherent contradictions. This way, during a projection, when the cold, petrified, and obdurate structure is flooded with an elusive image or an emotionally-charged narrative, the taken-for-granted narrative is suddenly deconstructed. The viewers may feel prompted to reflect upon the official intended meaning and function of civic architecture and a sense of abuse it elegantly and effectively conceals. As a result, a new, conflicting unity is created: what is projected and what it is projected onto are held together by two converging frames: the edges of the slide and the shape of the structure underneath. Over the years, such clashing of the official historical-political narrative with that of the unrepresented or repressed has become Wodiczko's artistic trademark, as, in the words of Rosalyn Deutsche, he often makes the "excluded material ... [return] within the vehicle of its repression." 10

As the chief intellectual framework for his artistic interventionism, the theoretically vocal Wodiczko lists the scholarship of Chantalle Mouffe, Michel Foucault 
and depth psychology. He is also very much aware of the tradition of post-Marxism (Gramsci, Habermas) and philosophy of the Other, as elaborated in the works of Emmanuel Levinas, Étienne Balibar and Giorgio Agamben. This all offers rich material for academic interpretations, which has been done extensively and convincingly by such scholars as Deutsche, Dora Apel, Bożena Czubak, and Ewa Lajer-Burcharth. ${ }^{11}$ What is more, in "Subversive Signs," Hal Foster locates Wodiczko among artists who understand the status of art not as a formal or perceptual experiment, but as "a social sign entangled with other signs in systems productive of value, power and prestige," a sign that "seeks out its affiliations with other practices (in the culture industry and elsewhere)." Within this framework, the artist "becomes a manipulator of signs more than a producer of art objects" in order to "intervene in ideological representation and languages of everyday life." 12 This is why Foster calls such artistic practices "subversive signs," for they have a potential to disrupt existing chains of signifiers which are usually so sedimented in the collective worldview that they function as natural and neutral. Additionally, Wodiczko's art shares similarities with the Situationist movement. As noted by Nicolas Whybrow:

the experience of art, like the experience of the city, is embodied. It is dependent on participating entities who engage or interact with art, with the environing field of the city .... [The spectators] are, therefore, as much producers as consumers or recipients. The radical move out of the museum [is] a "reaching out" of art generally towards incorporating both participation and the everyday [...].1.

Similarly to the Situationists, Wodiczko's move "out of the museum" into the "environing field of the city" enhances the spectators' active participation in the projection and their going through an "embodied" experience. This experience can never be fully ritualized or refuted, for sensory experience is always immediate and the spectators can be drawn into becoming active participants of the event.

It 6 follows that Wodiczko's emphasis on the direct and relational (or even therapeutic) character of his work locates him among artists, who, since the 1980s, have engaged in critiquing the political from a position that has absorbed the developments within humanities, especially psychology and cultural studies. The emphasis put on the relational character of art has been inspired by psychologists such as Melanie Klein, Donald Winnicott, and John Bowlby. ${ }^{14}$ As Rosalyn Deutsche has noted: "contemporary art, especially since the 1980s, has stressed that a work of art is not a discrete entity but, rather, a term in a relationship with viewers." Such art necessarily questions "rigid forms of identity" and perceives the subject as constantly on the make by coming into contact with other people. Since this subject-making has a relational character, there is "a convergence between contemporary art and psychoanalysis." 15 This understanding of the subject goes against the grain of what traditionally has passed as historiography in which "unitary, preconstituted, and self-possessed" 16 subjects perform actions in the name of a people. Deutsche notes that especially feminism has "explored the role played by totalizing images in producing and maintaining heroic, which is to say, warlike subjects." ${ }^{17}$ Wodiczko shares the feminist/ psychoanalytic critique of subjectivity, maintaining that the subject is fundamentally a "question," formed "by the relationship between the self and the other in the polis." 18 Thus, according to Deutsche, he belongs within "the feminist practice of contemporary art that produces what have been called critical images, images that undo the viewing subject's narcissistic fantasies." ${ }^{19}$ In accordance with Deutsche's observations, Wodiczko perceives subjectivity as neither monolithic nor fully self-aware, which makes it 
possible for art to produce shifts in its complex and opaque structure. Already in the 1980s, Wodiczko explained the psychoanalytical aspect of his art: he projects at night when "the building sleeps, when it dreams its nightmares" and when "the excluded [elements] come back as ghosts to haunt the places that expelled them." ${ }^{20} \mathrm{He}$ thinks of his projections as of "public psychoanalytical séances, unmasking and revealing the unconscious of the building, its body, the 'medium' of power" ${ }^{21}$ through an act of "emotional artistic communication." ${ }^{22}$ This is why he finds his projections effective only when there is "an emotional engagement and a critical detachment." ${ }^{23}$ Because the projection simply happens to individual spectators and disturbs them by acting directly on their minds, senses and bodies, it produces short-circuits, forestalling the routinely followed mind-paths. ${ }^{24}$

As I am going to demonstrate in this essay on the example of the two Union Square projections, the above reservoir of ideas underpins Wodiczko's artistic interventionism and translates into the ways in which he comes in a dialogue with civic urban architecture. Wodiczko notes that the major reason for civic architecture's ideological effectiveness is that its symbolism is hardly ever questioned, this is why it retains a "disciplining function." ${ }^{25} \mathrm{He}$ puts it in the following way: "The [civic] building is not only an institutional 'site of the discourse of power,' but, more importantly, it is a meta-institutional, spatial medium for the continuous and simultaneous symbolic reproduction of both the general myth of power and the individual desire for power."26 Since most city inhabitants pass by those grand structures every day without paying attention to them and yet, subconsciously or not, acknowledge their authority, civic architecture remains a mute yet powerful supporter of the biopolitical status quo and successfully legitimizes the official narrative. Wodiczko notes:

Circulating around and between the buildings, we cannot stop moving. We are unable to concentrate and focus on their bodies. This establishes an absent-minded relation to the building, an unconscious contact, a passive gaze. By imposing our permanent circulation, our absent-minded perception, by ordering our gaze, by structuring our unconscious, by embodying our desire, masking and mythifying the relations of power, by operating under the discreet camouflage of a cultural and aesthetic "background," the building constitutes an effective medium and ideological instrument of power. ${ }^{27}$

8 This way civic buildings and memorials act as purely aesthetic anesthetics (note the pun here: aesthetics/anesthetics): with their perfect proportions and neoclassical façades, they are aestheticized masks that cover up the violence and tragedies that happened in their name. They allow for a smooth and officially legitimized (or even enhanced) repression of the traumatic dimension of the celebrated or commemorated event. What is more, because of people's "daily inattention," to use Bataille's term, ${ }^{28}$ their original meaning is often not even acknowledged and thus becomes almost irrelevant. What remains is the aura of authority that radiates from such architecture, often experienced as a physical sensation when passing by a governmental building: the site of Prime Minister, the building of Congress, a prison, etc. It is an impression that the building's gaze hits the skin on one's cheeks as one physically feels the power and the possible abuse the building is imbued with.

The idea of bringing together conflicting narratives is very much present in the two Union Square projections that I now would like to focus on. In both, Wodiczko took "advantage of the prestige of historical symbolic structures ... that bear witness to events and stand for their authority" ${ }^{29}$ and protested "the monopolization of collective 
memory with a working on various different memories." ${ }^{30}$ In both, the artist cast images of the repressed (of the homeless and of suffering war veterans) against the beacons of authority and tradition - the statues of American national heroes. His choice of the place was also not accidental. Union Square, located at the meeting point of Broadway, Park Avenue and $14^{\text {th }}$ Street, and bordering with Chelsea, East Village, and Greenwich Village, belongs among American National Historic Landmarks and is known for its long tradition of political demonstrations and gatherings. Opened to the public in 1839, in 1882 Union Square hosted the first Labor Day parade in the U. S. and until today functions as a meeting place in times of social unrest. For example, after the attacks of $9 / 11$, the square became the first spontaneous gathering site for people who came to mourn the victims, light candles and hold vigils in their honor. Significant is also the very topography of the Square. Filled with a carefully designed oval park, Union Square hosts the "majestic presence" ${ }^{31}$ of four neoclassical statues that Wodiczko used in his projections: the statues of George Washington, Abraham Lincoln, Marquis de Lafayette, and the previously mentioned Allegory of Charity. Placed in the square's most representational venues, with the monumental equestrian bronze statue of George Washington occupying the very center of the park, the statues honor American national heroes and reward charity. All four statues were unveiled in the late $19^{\text {th }}$ century as part of the municipal art movement that was to "create order and tighten social control in the American city" ${ }^{32}$ in the turbulent times of the city's rapid industrialization and large immigration. As pointedly noted by Christine Boyer:

[N]eoclassical imitations of Greek and Roman sculptures were designed to conceal social contradictions by uplifting "the individual from the sordidness of reality" through the illusions of order, timelessness, and moral perfection that neoclassicism was supposed to represent. ${ }^{33}$

10 Significantly, the same kind of rhetoric was used in the 1980s when New York was undergoing intensive and extensive revitalization that produced the context for Wodiczko's 1986 Homeless Projection. For example, the 1980s senior architecture critic of The New York Times Paul Goldberger praised the square's "finest statuary" that preserves its merit even if "a derelict is relieving himself beside it." ${ }^{34}$ Echoing Boyer, Rosalyn Deutsche identifies the use of the statues in the process of the city's revitalization as an attempt to "restore to the city a surface calm that belies underlying contradictions. ${ }^{35}$ TheHomeless Projection visually brought the contradictions into the open. Onto the surface of the statues he cast images of homeless people that completely filled the statues in: thus the equestrian Washington was as-if put in a wheelchair, Lafayette and Lincoln became handicapped social outcasts, and the Allegory of Charity turned into a begging mother, clinging to her hungry children. The projection was the artist's response to the whitewashed sense of history and injustice covered up by the falsely depoliticized language of aesthetics and past glory. It also offered a critical comment on the link between "the production of cultural space and the production of homeless," 36 triggered by New York's revitalization.

What is more, Wodiczko's Homeless Projection coincided with the redevelopment of Union Square's park itself, which, in the official narrative, involved the eviction of the "socially undesirable population." ${ }^{37}$ In fact, as part of the revitalization of Union Square's area, "luxury condominiums, lavish corporate headquarters and high-rent offices ... proliferated ... [eroding] the existing low-income housing stock, thereby destroying the conditions of survival for hundreds of thousands of the city's poorest residents" 38 who were removed from the revitalized areas. This social abuse was 
masked under an aesthetic narrative which, in the case of Union Square, exploited the symbolic potential of the statues of American celebrated figures (Washington, Lincoln) for self-legitimization. The "majestic presence" of "bronze statues as representatives of eternal values - aesthetic and moral" ${ }^{39}$ functioned as "an aesthetic disguise for revitalization" and was manipulated into what Wodiczko calls "a journey-in-fiction" ${ }^{40}$ that is presenting the revitalization as something unambiguously positive and desired by all, purposely silencing its human cost. As Denis Hollier has noted on a more general note, "art's political neutrality is the favorite alibi for operations that are neither neutral nor artistic." ${ }^{41}$ In his projection, Wodiczko exposed this hypocrisy and made visible the fact that by revitalizing an area, the city does not get rid of its social problems - they forcibly disappear in one place just to appear in another. This was the case with New York's redevelopment: it is estimated that by 1989 there were 10,000 people living on the streets of the city. ${ }^{42}$ What is more, the revitalization questioned the very idea of the public space being an arena available to all, as, in fact, it turned out to be fully accessible only to those wealthy enough to live elsewhere. The most vivid manifestation of this exclusion was the decision to bulldoze the park "in preparation for the first phase [of the restoration] ... [which] thoroughly reorganized the park's patterns to permit full surveillance of its occupants," thus assigning architecture "the role of policing urban space." 43 Thus the public character of Union Square turned out to be conditional upon the hegemonic constraints imposed by the city establishment and business.

In 2012, in War Veteran Projection,Wodiczko returned to Union Square, this time animating Lincoln's statue only. By overlapping its shape with talking images of American war veterans from Afghanistan and Iraq, he focused on another area of pain usually excluded in the mainstream discourse. In this projection, returned male and female soldiers delivered individual testimonies of the psychological effects of combat they could not foresee. One after another they painfully confessed: "I could not be close to anybody," "I've [become] an undifferentiated schizophrenic," "I can see my eyes just tired and lifeless," "The daydreams, they sneak up upon you ... and you don't know how to defend yourself," which was intertwined with descriptions of horrific experiences they had been through and to which they, as soldiers, had frequently actively contributed ${ }^{44}$ In the testimonies, the emphasis was put on the emotional costs of war that very often are not acknowledged in the mainstream media which usually tend to focus on the physically injured and the dead. This mainstream narrative operates with statistics and claims to present "facts," usually silencing or depreciating the psychological dimension of war. In his New York Times article, Nicolas Kristof quotes Iraq veteran Ben Richards who explains that "Coming from an Army ethos ... you're not even entitled to complain unless you've lost all four limbs." Contrary to the mainstream image, Kristof observes that "traumatic brain injury and post-traumatic stress disorder ... are the signature wounds of the Iraq and Afghan wars." ${ }^{45}$ Further he states that:

The United States is now losing more soldiers to suicide than to the enemy. Include veterans, and the tragedy is even more sweeping. For every soldier killed in war this year, about 25 veterans now take their own lives. ${ }^{46}$

These words appeared in the official trailer of Wodiczko's 2012 projection, released by nonprofit organization More Art that was responsible for producing the projection. ${ }^{47}$ Kristof's observation was a significant reference point for the artist, as War Veteran Projection clearly has a therapeutic dimension. In a two-fold process, Wodiczko first 
encouraged the veterans to work out the best linguistic expression for the way they felt. Then for a month, their recorded testimonies, accompanied by their moving images, were displayed on the Lincoln statue in Union Square, a witness to a multitude of previous protests and lamentations. The veterans' individual voices, gestures and interrogations were blurred with the authoritarian, immobile, lofty statue of Lincoln, an icon of American patriotism in its tragic dimension. This way, there was "a passage from individual testimony" to "a public action" and thus "a secret trauma" became part of "social criticism." 48 Crucially, as observed by Bożena Czubak, "[the veterans'] voices and testimonies of wartime and post-war traumas contradicted the media universalization of wars and their victims, transformed into objects of noncommittal empathy." ${ }^{49}$ Wodiczko then did not address the mainstream discourse on its own terms, instead he provoked the spectator to ask the question of "What kind of vision might overcome apathy and respond to the suffering of others?" ${ }^{50}$ It echoed the observations put forward in the book authored by Wodiczko, titled The Abolition of War (2012). There, the artist quotes Bronislaw Malinowski, Roy L. Prosterman and Margaret Mead who juxtapose the universalizing language of war with that of the individual suffering. They emphasize the tragically effective role of perceiving the "enemy" through the lens of collective identities that divide the world into "us" and "them." This split perception dehumanizes "them" and allows for an ideologically justified killing of "nonindividualized members of the other community" 51 who become a legitimate target that needs to be annihilated.

Wodiczko's effort to disrupt the above perceptual jump from the empathetic individuality to the rationalized collectivity is, in my view, the unifying element of all his art. This attempt is also reflected in the two projections carried out in Union Square. Despite the differences, The Homeless Projection and War Veteran Projection have been designed to appeal not only to one's intellect (rationality), but also - to one's emotional and physical sensitivity (empathy). Additionally, in both,what is projected and the projection's addressees are individual people. More than that, when comparing the two projections, one notes Wodiczko's growing radicalism. The immobile slides of undifferentiated homeless people of the 1986 projection, in 2012 gave way to moving images of singular veterans sharing their intimate and painful stories. The artist has also increased the collaborative engagement on the part of himself and the veterans, but also on the part of the spectators who are prompted to empathetically witness the traumatic stories. This therapeutic effect is further strengthened by Wodiczko's making use of Foucault's observations on parrhesia ("fearless and free speaking"). Unlike Foucault, the artist emphasizes the singular and relational character of the encounter between the teller and the witness which is evoked during the projection. He claims: "It must be assumed that those who bravely come forward with the otherwise unsolicited, often unspeakable truth need others who can open themselves up to bravely listen, open their ears." ${ }^{2}$ Significantly, for Wodiczko, this individual encounter between the teller and the witness constitutes the foundation not only of his projections, but also of democracy as such:

Foucault's demand for the ethics of the "self" and "care of the self" on the part of the potential parrhesiastic speaker ... becomes today the Democratic Project. ... [W]ithout a solid social, psychological, cultural, artistic, technological support and without the help of the community ... the potential fearless speakers ... will remain unable to open up and openly speak out in public space. They will remain silent. ... They need, what I call monument therapy. ${ }^{53}$ 
Even though the The Homeless Projection and War Veteran Projection differ, they share this basic belief in the validity of an individual, multi-layered encounter between a "fearless speaker" and an emphatic witness. It is through this encounter that a larger democratic awareness can be built, based on a nominalistic rather than collective perception of others. In the remaining part of the paper, I would like to take a closer look at the two projections and discuss their inherent problematics, addressing questions concerning their status, politics of representation, and - eventually - effectiveness.

First of all, Wodiczko's choice of Union Square as a place to display his projections brings to mind Gramsci's idea of the compromise equilibrium, according to which the privileged presuppose "that account be taken of the interests and the tendencies of the groups over which hegemony is to be exercised." ${ }^{54}$ By choosing a public square that has long functioned as a protest area, Wodiczko safely stays within the constraints imposed by hegemony, carefully negotiating the level to which his art can be effective.This rings in accord with Henri Lefebvre's understanding of the capitalist "production of space." Under this logic, Union Square has been produced as a public space, thus one of its very functions is to be a vent for various voices to speak. This public space is an "allowed for" or even, to some extent, a "designated" space for voicing protest. As Rosalyn Deutsche notes in the context of New York's 1980s revitalization, the very word "public" very often functions as a major semantic pacifier:

Citing "the public," whether this word is attached to art, space, or any number of other objects, ideas, and practices, is one means of providing the uneven development of New York with democratic legitimacy. ... Rather than a real category, the definition of "the public," like the definition of the city, is an ideological artifact... ${ }^{55}$

17 What is more, by assigning the public space the role of a protest area, it becomes falsely depoliticized, turning its subversive potential into that of an assigned a priori function. Let me quote Deutsche again: "Instrumental function is the only meaning signified by the built environment" which comes from the fake assumption of the "functionalization of the city, which presents space as politically neutral, merely utilitarian." ${ }^{56}$ Within this logic, various urban spaces are given various functions: shops are for shopping, train stations for commuting, parks for strolling, and protest areas for voicing protest. It is acknowledged that people need a place to protest: professor of philosophy Paul Scheffer explains that it is crucial to allow people to express their anger and frustration with words, to verbally demonstrate it. Without this vent, anger easily turns into violence. As he notes, "Debate makes hot heads cool down." ${ }^{57}$ So while the choice of Union Square to some extent deprives the protest of its disruptive, anarchistic potential, in the same move it locates the protesters in a culturally silent protest area. If one can speak of the "proper uses of the city" within the Lefebvrian paradigm of the production of space, ${ }^{58}$ then the proper use of Union Square is to gather, demonstrate and critique. Thus Wodiczko, by projecting the city's ailments in a hegemonically recognized public space, has necessarily used the city "properly." This, however, as I am going to argue later on, may have made his message more, not less effective.

Anøther significant aspect is that the very idea of the public sphere seems problematic. In her essay on the public space, Nancy Fraser has convincingly critiqued Jürgen Habermas' classic discussion of the public sphere as a singular entity. Instead, she claims that there are numerous public spheres and very often those that have not 
achieved a status of an "officially recognized public space" prove more effective. With this in mind, Fraser considers two relevant questions: 1) Is a single public sphere always preferable to a nexus of multiple publics?; and 2) Should discourse in public spheres be restricted to deliberation about the common good rather than to "private interests" and "private issues"? ${ }^{59}$ Pointedly she argues that:

[P]ublic spheres themselves are not spaces of zero degree culture, equally hospitable to any possible form of cultural expression. Rather, they consist in culturally specific institutions - including, for example, various journals and various social geographies of urban space. These institutions may be understood as culturally specific rhetorical lenses that filter and alter the utterances they frame; they can accommodate some expressive modes and not others. ${ }^{60}$

While I find the observations by Deutsche and Fraser illuminating, it seems to me that in his two Union Square projections, Wodiczko cleverly used their reservations to his advantage. Clearly, by projecting images upon the emblematic statues on an "official" public arena (that is: using the city "properly"), he did not challenge the function assigned to the place by the urban planners. However, as his projections were not spontaneous protests, but carefully designed artistic gestures, they acquired a performative character. In other words, in both cases, they were prearranged, staged acts of protest display. Referring to Foster's observations on the manipulation of signs, what Wodiczko did was combine the socio-political aura of Union Square with the authority of a recognized artist and a university professor in a performative act of public projection. The two projections were not acts of protest per se, but its performances. This performative re-enactment of the protest idea by an established artist and scholar fundamentally changes the status of the event. Locating the projections (artistic performative acts) in a place of great cultural saliency translates singular images/testimonies into a manifesto. In effect, Wodiczko turns a "private issue" of individual suffering (homelessness and war trauma) into an artistic and political statement.

However, the conflation of the private with the political on the level of an individual spectator poses, in my view, major difficulty. The reason is that it prompts the spectator to realize that the official discourse and one's own world view are to a large extent communicating vessels: often what is repressed in the hegemonic discourse translates into one's own repressions. Such realization often proves difficult or even impossible, as repression generally provokes resistance and denial. It is a fundamental belief of classical psychoanalysis that repression is a powerful defense mechanism that protects the subject, therefore confronting the repressed is always painful. As the repressed contents allow for a superficial integrity of the subject, the subject is very resistant to any attempts of bringing the repressed into consciousness. Acknowledging the repressed involves uncovering a trauma in a painful move, which dismantles the subject's structure and ruins one's carefully elaborated self-image. This is why it seems that Wodiczko was very clever in choosing the location of Union Square as his vehicle to bring back the repressed dimensions of culture. Confronting them may be easier in the context of a place that has a long tradition of hosting various "returns" of the repressed.

Last but not least, in the 2012 projection, Wodiczko exploited the medium of individual testimony, a medium which has been brought to saliency, but at the same time has become formalized or even ritualized by the literature of the Holocaust. Again, the artist's choice proves to be a two-edged sword. Even though testimony may seem 
overexploited or even clichéd, still, by its strong associations with the traumatic narratives of the Holocaust, it is a powerful, heavily cathected connotative tool. By resorting to this particular genre, Wodiczko's War Veteran Project effectively counteracts the official narrative, triggering in the viewers a certain emotional and reflexive mood, which may not even be consciously realized. By appealing directly to the spectators' senses, emotions, and minds, Wodiczko exposes them to an experience which is not only to be reasoned, but first of all - lived. This experience ignites a train of emotional and semantic associations that may alter their mind frame.

Inexonclusion, I want to stress that the possible effectiveness of Wodiczko's artistic interventionism rests on the assumption that his art is relational and that this relation is not abstract, but singularly created when a spectator empathetically witnesses a projection (goes through a lived "embodied" experience). In his projections, Wodiczko connects "the psychic with the political," ${ }^{61}$ following the feminist tradition which "has long insisted on the inseparability of the personal and the political and on politics concerned with subjectivity." ${ }^{2}$ By skillfully manipulating cultural signs (e.g. "Union Square," "Washington," "Lincoln," "patriotism," "the public space," "the testimony," "the witness"), he cuts across the boundaries of art and activates in the spectators trains of semantic associations. This intention is reflected in Wodiczko's words, calling on for an amalgamate of experience: "To get fit and fully able in terms of democracy, the city has to look at itself from the perspective of its ailments: physical, social and psychological." ${ }^{33}$ Lately, the artist seems to be growing impatient. The already mentioned book Abolition of War is very prescriptive, as Wodiczko calls for a total abandonment of war, which he hopes one day will become a regrettable historical institution. Even if not yet effective, it is still worth trying. Because, as Wodiczko claims, "democracy is a job, you don't find it, you make it."

\section{NOTES}

1. By projection I mean here casting an image or a prerecorded audio\&video material onto the surface of a statue/monument/building. The term will be discussed in detail later in this essay.

2. While the original title was The Homeless Projection: A Proposal for the City of New York, it was then changed to The Homeless Projection: A Proposal for Union Square. For more detail check Rosalyn Deutsche's “Krzysztof Wodiczko's Homeless Projection and the Site of Urban 'Revitalization,"' in Krzysztof Wodiczko, ed. Duncan McCorquodale (London: Black Dog Publishing, 2011), 116.

3. This projection exists only in the form of a proposal that was exhibited at 49th Parallel, Centre for Contemporary Canadian Art.

4. Bożena Czubak, ed., Krzysztof Wodiczko: War Veteran Projections (Lublin: Galeria Labirynt 2013), 64.

5. Rosalyn Deutsche, "Krzysztof Wodiczko's Homeless Projection and the Site of Urban 'Revitalization,'” in Krzysztof Wodiczko, ed. Duncan McCorquodale (London: Black Dog Publishing, 2011), 127. 
6. One can find an illustrated and theorized guide to Wodiczko's projections in, among others: Bożena Czubak (ed.) Krzysztof Wodiczko: Art of the Public Domain (2011) and Duncan McCorquodale (ed.) Krzysztof Wodiczko (2011).

7. Wodiczko quoted in: Bożena Czubak, "Art of the Public Domain," in Krzysztof Wodiczko: Art of the Public Domain, ed. Bożena Czubak (Sopot: Państwowa Galeria Sztuki: 2011), 16.

8. In the early projections, Wodiczko made use of still slide images, with time he gradually turned to projecting prerecorded audio-visual narratives.

9. Wodiczko has called civic architecture "a spectacle of images of social stability." In: Bożena Czubak, "Art of the Public Domain," 18.

10. Deutsche, "Krzysztof Wodiczko's Homeless Projection," 132.

11. For example see: Dora Apel, "Technologies of War, Media, and Dissent in the Post-9/11 Work of Krzysztof Wodiczko," in Krzysztof Wodiczko, ed. Duncan McCorquodale (London: Black Dog Publishing, 2011); Ewa Lajer-Burcharth, "Borders," in Krzysztof Wodiczko: Guests/Goście, ed. Bożena Czubak (Warszawa: Galeria Narodowa ZachĘta, 2009); Bożena Czubak, "Art of the Public Domain,” in Krzysztof Wodiczko: Art of the Public Domain, ed. Bożena Czubak (Sopot: Państwowa Galeria Sztuki: 2011).

12. Hal Foster, "Subversive Signs," in Recodings: Art, Spectacle, Cultural Politics (New York: The New Press, 1985), 99-100.

13. Nicolas Whybrow, Art and the City (London and New York: I.B.Tauris, 2011), 15.

14. The therapeutic aspect of art is discussed in more detail in the article by Eva Marxen, "Therapeutic Thinking in Contemporary Art or Psychotherapy in the Arts," The Arts in Psychotherapy 36 (2009), 131-139.

15. Deutsche, Hiroshima after Iraq: Three Studies in Art and War. (New York: Columbia University Press 2010), 7.

16. Ibid., 5 .

17. Ibid., 4.

18. Leung qtd. in Deutsche, Hiroshima after Iraq, 5.

19. Deutsche, Hiroshima after Iraq, 67.

20. Denis Hollier, "While the City Sleeps: Mene, Mene, Tekel, Upharsin," in Krzysztof Wodiczko, ed. Duncan McCorquodale (London: Black Dog Publishing, 2011), 197.

21. Wodiczko, "Public Projection," 49.

22. Krzysztof Wodiczko, "Art of New Public Domain," in Krzysztof Wodiczko: War Veteran Projections, ed. Bożena Czubak (Lublin: Galeria Labirynt 2013), 21.

23. Wodiczko, "Public Projection," 49.

24. In Poland, there is another artist whose art is reminiscent of Wodiczko's. Joanna Rajkowska, by creating unfamiliar contexts and locating them in familiar yet traumatic places, experiments with participants' reactions and opens up new dimensions to address the past and demand a new type of discourse. In her public installations, she makes things visible in a new way by directly affecting the senses of the recipients: confronted with her works, they cannot resist being somehow affected, feeling something. I have analyzed several of her public installations in the article "Polish Colonial Past and Postcolonial Presence in Joanna Rajkowska's Art" published in At the Cross-Words: Theorizing Race, Ethnicy and Postcolonialism, Ewa Luczak, Justyna Wierzchowska and Joanna Ziarkowska ed. (Frankfurt, Berlin, New York: Peter Lang, 2011).

25. Czubak, "Art of the Public Domain," 17.

26. Krzysztof Wodiczko, "Public Projection," in Krzysztof Wodiczko, ed. Duncan McCorquodale (London: Black Dog Publishing, 2011), 48.

27. Wodiczko, "Public Projection," 48-49.

28. Hollier, "While the City Sleeps," 200.

29. John Rajchman, "Critical Guests," interview with Krzysztof Wodiczko, in Krzysztof Wodiczko: Guests/Goście, ed. Bożena Czubak (Warszawa: Galeria Narodowa Zachદ̨ta: 2009), 10. 
30. Czubak, "Art of the Public Domain," 19.

31. Paul Goldberger quoted in Deutsche, "Krzysztof Wodiczko's Homeless Projection," 113.

32. Deutsche, "Krzysztof Wodiczko's Homeless Projection," 121.

33. Qtd. in Deutsche, "Krzysztof Wodiczko's Homeless Projection, 121.

34. Qtd. in Deutsche, "Krzysztof Wodiczko's Homeless Projection," 113.

35. Rosalyn Deutsche, "Uneven Development: Art in New York City," October 47 (Winter 1988), 5.

36. Hollier, "While the City Sleeps," 198.

37. Deutsche, "Krzysztof Wodiczko's Homeless Projection," 114.

38. Ibid., 113.

39. Ibid., 128.

40. Qtd. in Deutsche, "Krzysztof Wodiczko's Homeless Projection," 114.

41. Hollier, "While the City Sleeps," 194.

42. "New York City Tableaux: Tompkins Square," in Krzysztof Wodiczko, ed. Duncan McCorquodale (London: Black Dog Publishing, 2011), 206.

43. Deutsche, "Krzysztof Wodiczko's Homeless Projection," 126.

44. Czubak, Krzysztof Wodiczko: War Veteran Projections, 65-71.

45. The emotional aspect of war is now starting to be noticed by American mainstream culture. For example, in the TV series Homeland it is given prominent visibility. Still, it is not presented as being acknowledged or processed, as main protagonists (both the veteran and the CIA agent) are not offered any psychological help. The veteran is put under CIA's surveillance, the agent is medicated.

46. Nicolas D. Kristof, "War Wounds," New York Times, 10 August 2012, http:// www.nytimes.com/2012/08/12/opinion/sunday/war-wounds.html?pagewanted=all\&_r=0 .

47. On the official website of More Art one reads: "More Art is a federal nonprofit organization dedicated to producing meaningful and engaging works of public art in New York City."More Art garners the power of public art to encourage social change and bridge the gaps existing between underserved communities and the general public in New York City. We make art accessible to all by fostering artistic collaborations between contemporary artists and local communities and locating all our projects in freely accessible public spaces. We support artists in their creative endeavors and provide a public platform of expression for artists and community members to express themselves through art" (http://moreart.org/mission-history/).

48. Andrzej Turowski, "Przemieszczenia i obrazy," in Krzysztof Wodiczko, ed. Duncan McCorquodale (London: Black Dog Publishing, 2011), 294. In his text, Turowski referred to another projection by Wodiczko carried out in Tijuana, Mexico in 2001. However, as the projection also made use of individual testimonies, I believe that Turowski's observations may be applied to the projection carried out in Union Square as well.

49. Czubak, "Art of the Public Domain," 22.

50. Deutsche, Hiroshima after Iraq, 64.

51. Krzysztof Wodiczko, Obalenie wojen (Kraków: Muzeum Sztuki Współczesnej, 2012), 9-11.

52. Krzysztof Wodiczko, "Monument, Parrhesia, Projection," in Krzysztof Wodiczko: Art of the Public Domain, ed. Bożena Czubak (Sopot i Warszawa: Państwowa Galeria Sztuki i Fundacja Profile: 2011), 166.

53. Wodiczko, "Monument," 167.

54. Qtd. in John Storey, Cultural Theory and Popular Culture: A Reader (London: Harvester Wheatsheaf, 1994), 216.

55. Deutsche, “Uneven Development," 10,12.

56. Ibid., 6.

57. Paul Scheffer, “Spierajmy się, jak razem żyć." Gazeta Wyborcza, No. 7 (8340), 10-11 January, 2014. 19. 
58. For a more detailed discussion of the proper use of city spaces, see: Rosalyn Deutsche's "Uneven Development."

59. Nancy Fraser, "Rethinking the Public Sphere: A Contribution to the Critique of Actually Existing Democracy," Social Text 25/26 (1990), 62.

60. Fraser, "Rethinking the Public Sphere," 69.

61. Deutsche, Hiroshima after Iraq, 62.

62. Ibid., 4.

63. Wodiczko, "Monument," 166.

\section{ABSTRACTS}

This essay discusses two projections by Polish-born artist Krzysztof Wodiczko carried out in Union Square in the city of New York. The Homeless Projection: A Proposal for Union Square (1986) and Abraham Lincoln: War Veteran Projection (2012) address major ailments of modern society: homelessness and the psychological effects of war. By casting images on the statues of American heroes, the artist clashes the official historical-political narrative with that of the unrepresented or repressed. In the two projections carried out in Union Square, Wodiczko makes use of the public space to performatively re-enact social protest in a culturally salient locus. The article presents the subversive potential of the two projections and discusses their inherent problematics, referring to observations by Jürgen Habermas, Nancy Fraser, Rosalyn Deutsche, and others.

\section{INDEX}

Keywords: Afghanistan, contemporary art, homelessness, Iraq, Krzysztof Wodiczko, public space, Union Square, war

\section{AUTHOR}

\section{JUSTYNA WIERZCHOWSKA}

Institute of English Studies, University of Warsaw 